\title{
The Curious Case of a Medical Oncology Resident
}

In August 2015, as I joined my medical oncology residency, the stress that a medical oncology residency brings along with it was well known. Some of them ended with the resident quitting the institution in search of greener pastures. The thought of such attrition in the past batches was more concerning than the actual daily experiences. The huge monetary fine attached was scary too. The reason for choosing an institute like ours was obvious. Being the most reputed oncology institute in the country and even having a good name abroad, work schedule was expected to be heavy. We wondered why would then someone take an extreme step of bidding adieu. As 2 months passed and none of us had left the course, we were set to create a new benchmark.

\section{Dilemma of Death, Hope of Quality of Life}

Then, it happened. One of my coresidents decided to leave the course. That evening, I rushed to his room to talk before he submitted his papers. As a brilliant internist from a reputed medical college and a compassionate guy, I wanted him to continue. He opened his emotions to me then. He was posted in the general outpatient department (OPD) and was entitled to see the new patients with lung cancer. Hence, at the end of each history, examination, and workup, he realized most of them are at Stage 4. The burning questions of life and death he faced from each of the patient and family troubled him. Never before, apart from outside an intensive care unit (ICU) in his MD, had he constantly been engaged in such conversations. Being a compassionate soul, he could not avoid their queries either.

Immunotherapy in 2015 was limited to melanoma and even now is not a cup of tea for a general patient anyway. A patient with epidermal growth factor receptor mutation and those in trials were blessed ones. He saw others as if they were staring at their doom. In the evening and late night, as he helped in data entry of lung cancer audit, he realized that the survival period in such cases is hardly less than a year. And there were young and old patients in the cohort. I listened to him with all my attention. He wished to leave and prepare for a specialization in Gastroenterology. I agreed that it was his choice to make and is free to take the decisions. However, this is a real-life situation that needs to be dealt with.

In India, $60 \%-80$ of patients do come in advanced stages of cancer. They come with all their hope to us and with burden of their symptoms. As an oncologist, we treat the patient, not the cancer cell alone. If we can reduce his pain or if by doing a pleural tap, he breathes better, we have helped him well. The concept of palliative care is of paramount importance to each one of us as it is for patients. We must take this initiative on the $1^{\text {st }}$ day we see the patient. With relieve patient and less anxious relatives, when we talk about the benefit of chemotherapy even if it is in months, it makes sense. The data that we see from the records are true but can never predict the life of the individual sitting in front of us. Early palliative care and quality of life must be understood well before one gets fascinated by the charms of checkpoint inhibitors. Leaving them to their fate is akin to the ostrich burying head in the sand. Facing the true life as it is and being the source of their comfort suits his kind soul than this decision. He looked glad at the end of our talk and stayed back.

\section{Blues of Burnout}

After the initial days of uncertainty, the residents then get deeply involved in patient care and cancer research too. The display of vastness of oncology is truly mesmerizing. In our hospital, the spectrum of patients also is very wide in terms of rare versus common cancers, poor versus very rich, state from which they come, and languages, etc. The dedication of nurses, medical social workers, occupational therapists, and discussion in the multidisciplinary tumor boards is inspiring. The intensity of clinical work and cancer research, however, does take a toll on a resident's wellbeing. Few residents are unable to cope up with this workload. Once a hardworking junior who recently got married told me, he wishes to quit as he was unable to devote anytime to his family. However, I knew that was not the reason. He was posted in the ICU at that time and after long hours in the OPD; it was getting strenuous for him. And postmarriage, things got more demanding. Again, after days of talking with him, he reversed his decision to quit.

In a study of medical residents, nearly $60 \%$ had reported burnout and high psychological demand was identified as a predominant risk factor. ${ }^{[1]}$ In oncologists, especially younger than 40 years, it is about $70 \%{ }^{[2]}$ In a review article by Murali et al., risk factors identified include early career stage, increased workload, and poor work/life balance. They conclude that resilience is potentially a protective factor against burnout. ${ }^{[2]}$ A systematic review on effective strategies to reduce resident physician burnout analyzed 19 studies (6 randomized controlled trials, 13 cohort studies) enrolling 2030 residents and examining 12 interventions and found that limiting resident work hours (as per the Accreditation Council for Graduate Medical Education standards) was associated with decrease in emotional exhaustion component of burnout and overall burnout rates. There are concerns about restricting duty hours, leading to inadequate resident training. Meditation, self-care workshops, and improving peer relationships also were found to reduce burnout rate. ${ }^{[3]}$ 


\section{Being Victorious and Not Victim}

The organizational efforts that have been taken in our hospital include mentorship programs, promoting personal discussions between the residents and psychological support for the needy residents from trained psychologists. Any resident who goes into this difficult phase must communicate their concerns with their seniors, family, and if required, should not hesitate from taking professional help too. The privilege to be of service to cancer patients must be enhanced by the inner strength and joy which existing in each one of us and it is definitely possible.

\section{Burnout}

I was not like this before, but then since few days,

In the crowd around, mute I stood, amidst all sound Silently, I listen, my heart heavy, feel as if wound,

Of work, after duty call, my dreams drift, they fall,

In hard labor, flask of life seemed null and void,

Ward to ward, from bed to bed, as I moved

Learning how well to care; weak eyes endure

Not enough energy, no light I saw ahead

Seem dark deep inside too, l listened instead...

\section{Resilience}

In depth of my Soul, Inner Voice I hear

Words are soothing, they seem very clear

Patient's eyes radiate belief, plead some relief Gather my dear self, get go treat their grief

Its privilege unparalleled to heal unfortunate

There is power inside you to change their fate

Gear up to know secrets of cure and care

Pathways in cell, weird ways of cancer,

Your inner self is the source of all joy

Stay firm against the external world's ploy
Come on my body and mind, break the trends,

When the Inner Joy flows, the burnout ends.

\section{Sujith Kumar, Jyoti Bajpai}

Department of Medical Oncology, Tata Memorial Centre, Tata Memorial Hospital, Homi Bhabha National Institute, Mumbai, Maharashtra, India

Address for correspondence: Dr. Jyoti Bajpai,

Department of Medical Oncology, Tata Memorial Centre, Tata Memorial Hospital, Homi Bhabha National Institute, Dr Ernest Borges Marg, Parel, Mumbai - 400 012, Maharashtra, India. E-mail:dr_jyotibajpai@yahoo.co.in

Submitted: 17-May-2019 Revised: 11-Jun-2019 Accepted: 09-Jul-2019 Published: 24-Apr-2020

\section{References}

1. Rodrigues H, Cobucci R, Oliveira A, Cabral JV, Medeiros L, Gurgel $\mathrm{K}$, et al. Burnout syndrome among medical residents: A systematic review and meta-analysis. PLoS One 2018; 13:e0206840.

2. Murali K, Makker V, Lynch J, Banerjee S. From burnout to resilience: An update for oncologists. Am Soc Clin Oncol Educ Book 2018;38:862-72.

3. Busireddy KR, Miller JA, Ellison K, Ren V, Qayyum R, Panda M. Efficacy of interventions to reduce resident physician burnout: A systematic review. J Grad Med Educ 2017;9:294-301.

This is an open access journal, and articles are distributed under the terms of the Creative Commons Attribution-NonCommercial-ShareAlike 4.0 License, which allows others to remix, tweak, and build upon the work non-commercially, as long as appropriate credit is given and the new creations are licensed under the identical terms.

\begin{tabular}{|l|l|}
\hline \multicolumn{2}{|c|}{ Access this article online } \\
\hline Quick Response Code: & Website: \\
& www.ijmpo.org \\
\cline { 2 - 2 } & DOI: \\
\hline
\end{tabular}

How to cite this article: Kumar MS, Bajpai J. The curious case of a medical oncology resident. Indian J Med Paediatr Oncol 2019;40:49-50. 